\title{
ANALISIS LITERASI MEDIA TELEVISI DALAM KELUARGA

\author{
(Studi Deskriptif Pendampingan Anak Saat Menonton Televisi \\ Di SD Islam Al Ulum Terpadu Medan)
}

\author{
Oleh: \\ Rahmanita Ginting, Sri Pratiwi \\ Program Studi Magister Ilmu Komunikasi \\ Universitas Muhammadiyah Sumatera Utara \\ E-mail: rahmanitha@yahoo.com, rahmanita_ginting@umsu.ac.id
}

\begin{abstract}
Abstrak
Televisi merupakan media massa yang banyak dimanfaatkan oleh orangtua dan anak dalam memperoleh beragam informasi dan hiburan, namun tanpa memahami struktur pengetahuan dan keterampilan dalam literasi media maka orangtua akan kesulitan dalam memberikan informasi yang seimbang pada saat mendampingi anak menonton televisi. Penelitian ini bertujuan untuk menjelaskan struktur pengetahuan literasi media yang dipahami oleh orangtua dan menjelaskan keterampilan (skills) literasi media yang sebaiknya dimiliki oleh orangtua pada saat mendampingi anak menonton televisi di SD Islam Al Ullum Terpadu Medan. Penelitian ini menggunakan metode penelitian deskriptif kualitatif, yaitu mendeskripsikan pendapat objek yang diteliti berdasarkan fakta yang ada di lapangan mengenai literasi media dalam keluarga sebagai proses pendampingan pada saat menonton televisi pada anak di SD Islam Al Ulum Terpadu Medan. Subjek dalam penelitian ini adalah keluarga. Data dikumpulkan melalui wawancara, dan dokumentasi. Hasil penelitian menyebutkan bahwa struktur pengetahuan yang dipahami oleh orangtua meliputi pengetahuan isi pesan, pengetahuan industri media, dan pengetahuan efek media. Sedangkan keterampilan literasi media yang dimiliki orangtua sebaiknya meliputi analisis, evaluasi, pengelompokan, induksi, deduksi, sintesis, dan abstraksi. Namun pengetahuan dan keterampilan literasi media yang dimiliki oleh orangtua masih berada pada proses pemahaman saja, sehingga pada saaat mendampingi anak menonton televisi orangtua hanya memberikan informasi sekedarnya.
\end{abstract}

Kata Kunci: Literasi Media, Pendampingan menonton televisi, Keluarga

\begin{abstract}
Television is a mass media that widely used by parents and children in providing a variety of information and entertainment, but without understanding the structure of knowledge and skills of the media literacy as a parent would have difficulty in providing balanced information on when accompanying children watch television. The aims of this research are to describe the structure of media literacy knowledge that is understood by parents and explain the skills of media literacy that should be owned by a parent when accompanying children watch television at Al Ulum elementary Islamic school Medan. This research uses descriptive qualitative method; the research describes or depicts the researched object based on the facts regarding media literacy in the family as the process of accompanying children watch television at Al Ulum Elementary Islamic school Medan. Subjects in this research were family. Data were collected through interviews, and documentation. The results of this research that the structure of knowledge that is understood by parents include knowledge of the media contents, knowledge of media industry, and knowledge of media effects. The skills of media literacy possessed by the parents include analysis, evaluation, grouping, induction, deduction, synthesis, and abstracting. However, the knowledge and skills of media literacy that are owned by the parents are still in understanding level, so when accompanying children watch television the parents only provide simple information.
\end{abstract}

Keywords: Media Literacy, Accompanying children watch television, Family 


\section{A. PENDAHULUAN}

Media berpengaruh terhadap budaya khalayak dengan ragam cara. Maka tidak heran jika kehidupan masyarakat kita saat ini tidak bisa terpisahkan oleh kehadiran teknologi media komunikasi. Literasi media diperlukan akibat semakin gencarnya terpaan informasi dari berbagai media yang tidak diimbangi dengan kecakapan mengkonsumsinya, sehingga dibutuhkanlah pemahaman dalam mengkonsumsi media secara sehat (Baran, 2011). Banyaknya stasiun televisi yang bermunculan mulai dari stasiun televisi swasta nasional sampai pada stasiun televisi swasta lokal, akan mempengaruhi pola menonton masyarakat kita dikarenakan pada satu stasiun televisi saja bisa menayangkan hampir lebih dari dua puluh program dalam satu hari. Dan hampir dari dua puluh program tersebut akan menghasilkan dan mentransfer ribuan informasi kepada masyarakat.

Jam menonton televisi yang tinggi oleh anak-anak tentunya mempunyai resiko yang tidak bisa disepelekan, mengingat tidak semua tayangan televisi diperuntukkan bagi anak-anak aman di konsumsi oleh anak-anak. Informasi yang disampaikan oleh televisi bersifat mentransferkan nilai-nilai budaya dan juga realitas. Namun realitas dan nilai-nilai yang disampaikan tersebut merupakan realitas yang sudah dikonstruksi sehingga sesuai dengan target pasar dan persaingan industri media (Sunarto, 2009). Menanggapi hal tersebut, khalayak seharusnya lebih pandai dan kritis dalam memilah-milah informasi. Karena tidak semua informasi yang didapat merupakan informasi yang berguna dan benar.

Masyarakat Peduli Media (2012) melihat pada kenyataannya televisi memberikan pengaruh terhadap perkembangan otak pada anak yang sedang tumbuh kembang, antara lain menghambat perkembangan bicara, membaca verbal/pemahaman, perkembangan kecerdasan, ekspresi lewat tulisan, meningkatkan agresifitas, sulit membedakan kenyataan dengan palsu, serta terjadi ketidakseimbangan antara otak kanan dan kiri. Hal ini mengakibatkan anak tidak dapat fokus/konsentrasi pada hal-hal yang bermanfaat dalam kehidupannya, karakternya pun mulai berubah menjadi tidak realistis, tidak sabar menganggap semuanya instan, menjadi pasif sehingga muncul rasa tidak perduli dan kurang berempati, menirukan sifat buruk seperti adegan yang disaksikan, malas bergerak, cenderung mengalami obesitas, dan matang sebelum waktunya.

Program pendidikan SD Islam Al Ulum Terpadu diselenggarakan dengan menggunakan sistem "Terpadu” yang berarti keterpaduan antara ilmu pengetahuan dan teknologi (IPTEK) dengan iman dan takwa (IMTAK). SD Islam Al Ulum Terpadu ini merupakan salah satu sekolah unggulan, hal ini terbukti dengan beragam prestasi yang telah diraihnya, sekolah ini juga menerapkan sekolah full day yang menyebabkan anak-anak mengurangi waktu menonton televisi secara otomatis.

Rumusan masalah dalam penelitian ini adalah Bagaimanakah struktur pengetahuan literasi media yang dipahami oleh orangtua dalam pendampingan menonton televisi pada anak di SD Islam Al Ulum Terpadu Medan? Keterampilan (skills) literasi media apa sajakah yang dibutuhkan orangtua pada saat mendampingi menonton televisi pada anak di SD Islam Al Ulum Terpadu Medan? 


\section{B. TINJAUAN PUSTAKA}

\section{TEORI USES AND EFFECT}

Pemikiran ini pertama kali dikemukakan oleh Steven Windhal (1979), ini merupakan sintesis antara pendekatan uses and gratification dan teori tradisional mengenai efek. Konsep "uses” (penggunaan) merupakan bagian yang sangat penting atau pokok dari pemikiran ini. Pemikiran terpenting dalam teori uses and effects adalah penggunaan media massa dapat memiliki banyak arti dimana isi media tertentu dikonsumsi dalam kondisi tertentu, untuk memenuhi fungsi tertentu dan terkait harapan-harapan tertentu untuk dapat dipenuhi dan kebutuhan hanya salah satu dari faktor yang menyebabkan terjadinya penggunaan media. Dalam uses and gratifications, penggunaan media pada dasarnya ditentukan oleh kebutuhan dasar individu, sementara pada uses and effect, kebutuhan hanya salah satu dari faktor-faktor yang menyebabkan terjadinya pengunaan media. Harapan dan persepsi terhadap media, dan tingkat akibat kepada media akan membawa individu kepada keputusan untuk menggunakan atau tidak menggunakan isi media massa (Sendjaja, 2005: 22). Khalayak dikatakan aktif karena mereka memiliki pilihan untuk mengevaluasi berbagai macam tipe media untuk mencapai suatu tujuan komunikasi yang baik. Konsep "use” merupakan bagian yang sangat penting atau pokok dari satu pemikiran ini. Karena pengetahuan mengenai penggunaan media dan penyebabnya, akan memberikan jalan bagi pemahaman dan perkiraan tentang hasil dari suatu proses komunikasi massa (Sendjaja, 2004: 41).

Penggunaan media massa dapat memiliki banyak arti, ini dapat berarti exposure yang semata-mata menunjuk pada tindakan mempersepsi. Dalam konteks lain, pengertian tersebut dapat menjadi suatu proses yang lebih kompleks, dimana isi terkait harapanharapan tertentu untuk dapat dipenuhi, fokus dari teori ini lebih kepada pengertian yang kedua (Bungin, 2006: 291). Hasil dari proses komunikasi massa dan kaitannya dengan penggunaan media akan membawa pada bagian penting berikutnya dari teori ini. Hubungan antara penggunaan dan hasilnya dengan memperhitungkan pula isi media, memiliki beberapa bentuk yang berbeda (Sendjaja, 2005: 22), yaitu:

1. Pada kebanyakan teori efek tradisional, karakteristik isi media menentukan sebagian besar dari hasil. Dalam hal ini, penggunaan media hanya dianggap sebagai faktor perantara, dan hasil dari proses tersebut dinamakan efek. Dalam pengertian ini pula, uses and gratification hanya akan dianggap berperan sebagai perantara, yang memperkuat atau melemahkan efek dari isi media.

2. Dalam berbagai proses, hasil lebih merupakan akibat penggunaan daripada karakteristik isi media. penggunaan media dapat mengecualikan, mencegah atau mengurangi aktivitas lainnya, disamping dapat pula memiliki konsekuensi psikologis seperti ketergantungan pada media tertentu. Jika penggunaan merupakan penyebab utama dari hasil maka itu disebut konsekuensi.

3. Hasil ditentukan sebagian oleh isi media (melalui perantara penggunaannya) dan sebagian lain oleh penggunaan media itu sendiri. Oleh karenanya ada dua proses yang bekerja secara serempak yang bersama-sama yang menyebabkan terjadinya suatu hasil yang kita sebut "conseffects" (gabungan antara konsekuensi dan efek). Proses pendidikan biasanya menyebabkan hasil yang berbentuk "conseffect". Dimana 
sebagian dari hasil disebabkan oleh isi yang mendorong pembelajaran (efek), dan sebagian lain merupakan hasil dari suatu proses penggunaan media yang secara otomatis mengakumulasikan dan menyimpan pengetahuan.

Teori uses and effects dapat diaplikasikan dalam penelitian ini, karena pada masyarakat era informasi saat ini informasi banyak diproduksi, didistribusikan, disimpan, diterima pada waktu yang bersamaan dan hal tersebut dilakukan dalam berbagai macam bentuk dan dalam jumlah yang sangat besar. Sehingga sangat sulit bagi individu untuk menentukan informasi yang relevan. Melalui teori uses and effects menekankan bahwa terdapat pengetahuan pada penggunaan media dan penyebabnya.

\section{TELEVISI}

Media massa dan komunikasi yang bermedia massa melayani sejumlah fungsi. Sosiolog yang sekaligus ahli komunikasi massa, Charles Wright (dalam Ruben dan Stewart, 2013: 403-404), merinci empat fungsi komunikasi massa, antara lain: pengawasan (surveillance), korelasi (correlation), sosialisasi (socialization), dan hiburan (entertainment). Dalam lingkup penelitian terhadap efek media, para sarjana komunikasi telah mengidentifikasikan 3 (tiga) level berbeda dari dampak psikologis yang dapat ditimbulkan oleh kekerasan yang ditampilkan di media massa terhadap khalayak. Level tersebut adalah kognisi, afeksi dan perilaku dan juga merujuk pada perbedaan efek yang ditimbulkan oleh kekerasan di media massa (Bryant dan Thompson, 2002: 177). Beberapa penelitian yang meninjau efek media dari level kognisi menunjukkan bahwa "realita” yang digambarkan pada program televisi tidak selalu merefleksikan kenyataan yang sebenarnya terjadi di dunia nyata. Beberapa ahli mempercayai bahwa terlalu banyak menonton televisi cenderung membentuk persepsi dan kepercayaan khalayak sehingga mereka akan lebih terhubung dengan dunia yang ditampilkan televisi dibandingkan dunia yang sebenarnya. Efek media seperti inilah yang kemudian disebut sebagai fenomena konstruksi realitas oleh media (Bryant dan Thompson, 2002: 76).

\section{LITERASI MEDIA}

Literasi media merujuk kemampuan khalayak yang melek terhadap media dan pesan media massa dalam konteks komunikasi massa” (Tamburaka, 2013: 7). Literasi Media adalah suatu rangkaian perspektif yang kita gunakan secara aktif untuk menerpa diri kita dengan media untuk menginterpretasikan makna dari pesan-pesan (media) yang kita temui. Kita membangun perspektif kita dari struktur pengetahuan. Untuk membangun struktur pengetahuan, kita memerlukan peralatan dan materi-materi mentah. Peralatan tersebut adalah keterampilan kita. Sedangkan materi mentah tersebut adalah informasi yang kita dapat dari media dan dari dunia nyata (Potter, 2001: 22). Mengambil kendali adalah inti dari literasi media. Menjadi melek media memberikan kita perspektif yang lebih jelas untuk melihat batas antara dunia nyata dan dunia yang dihasilkan oleh media. (Potter, 2001: 14).

Istilah Media Literacy sering disalahartikan dengan Media Education. Literasi media bukanlah pendidikan, meski begitu untuk memahami literasi media juga diperlukan pengetahuan tentang media. Perbedaannya adalah pendidikan media memandang fungsi media massa yang senantiasa positif, yaitu sebagai a site of pleasure dalam berbagai bentuk 
sedangkan literasi media yang memakai pendekatan innoculations yang berupaya melindungi khalayak dari dampak buruk pesan media massa (Tamburaka, 2013: 11). Silverblatt (dalam Ginting, 2015: 243) menyebutkan empat tujuan literasi media yaitu: (1) Kesadaran kritis. Kesadaran kritis memberikan manfaat bagi khalayak untuk mendapat informasi secara benar terkait coverage (cakupan) media dengan membandingkan antara media yang satu dengan yang lain secara kritis. (2) Lebih sadar akan pengaruh media dalam kehidupan sehari-hari, menginterpretasikan pesan media. (3) Membangun sensitifitas terhadap program-program sebagai cara mempelajari kebudayaan. (4) Mengetahui pola hubungan antara pemilik media dan pemerintah.

Potter (2001: 15) menekankan bahwa literasi media dibangun oleh tiga pilar, yaitu:

1. Personal Locus merupakan tujuan dan kendali kita akan informasi. Ketika kita menyadari akan informasi yang kita butuhkan, maka kesadaran kita akan menuntun untuk melakukan proses pemilihan informasi secara lebih cepat serta menekan efek media.

2. Knowledge structure. Struktur pengetahuan merupakan seperangkat informasi yang terorganisasi dalam pikiran kita. Dalam literasi media, kita membutuhkan struktur informasi yang kuat akan efek media, isi media, industri media, dunia myata, dan diri kita sendiri,

3. Skills adalah keahlian untuk menganalisis, mengevaluasi, mengkategorikan, mensintesakan, mengkritisi isi media. Keahlian ini jika dilatih maka akan semakin kuat kemampuannya. Materi dan informasi mengenai media (knowledge structure) menjadi dasar bagi pengembangan kemampuan ini.

\section{Proses Dalam Literasi Media}

Dua proses dalam membangun literasi media (Potter, 2001: 23) Pertama, membangun struktur pengetahuan yang kuat. Kedua, bertindak dalam cara "media literate" selama berhubungan dengan media.

1. Struktur Pengetahuan

Struktur pengetahuan merupakan pondasi utama dalam membangun literasi media, karenanya struktur pengetahuan ini menjadi sangat penting dalam membangun perspektif literasi media bagi audiens media massa. Potter (2001: 33-35) menyatakan bahwa struktur pengetahuan merupakan seperangkat informasi yang terorganisasi dalam memori seseorang.

a. Struktur pengetahuan isi media (Media Content)

Struktur pengetahuan isi media adalah salah satu elemen literasi media yang penting karena pesan media tidak selalu seperti apa yang terlihat. Potter (2001: 33) menyebutkan bahwa manusia pada dasarnya tengah hidup dalam dua dunia yaitu dunia nyata (real world) dan dunia media. Dunia nyata dimana kita berada dalam interaksi langsung dengan orang lain. Sebagian besar kita merasa bahwa dunia nyata ini terlalu terbatas. Kita tidak bisa mendapatkan berbagai pengalaman dan informasi hanya dari dunia nyata. Selanjutnya, struktur pengetahuan isi media dapat dikategorikan dalam tiga golongan yaitu pengetahuan tentang berita, hiburan, dan iklan.

b. Struktur Pengetahuan Industri Media 
Potter menyatakan bahwa dalam berhadapan dengan literasi media, kita dapat menggunakan default strategy ataupun media literacy strategy. Default strategy memiliki tujuan untuk membangun kepuasan dengan level interupsi minimal. Dalam level ini berarti seseorang mengakses media dalam konteks pola kebiasaan (habitual pattern) yang berkembang pada masa lalu. Media literacy strategy memiliki tujuan untuk memahami dunia ekonomi dalam industri media. hal ini berarti mereka memiliki ekpektasi yang lebih tinggi terhadap hasil yang didapat dibanding sumber daya yang dikeluarkan. Orang-orang semacam itu menginginkan lebih dari kepuasan minimal dari mengakses media, mereka berpikir matang tentang sumber daya yang dimiliki dan menginginkan negosiasi untuk mendapatkan hasil yang lebih bernilai (Rifiani, 2014: 14).

c. Struktur Pengetahuan Efek Media

Pengetahuan efek media berkaitan dengan aspek perspektif dimensional (Potter, 2001: 23), yaitu:

1. Timing of Effect berhubungan dengan efek yang terjadi ketika kita berinteraksi dengan media. Efek media dapat bersifat jangka pendek maupun jangka panjang.

2. Type of effect, terdapat lima tipe efek media yaitu: (a) Efek kognitif (b) Efek sikap (c) Efek emosi (d) Efek psikologis (e) Efek perilaku

3. Valance of effect

4. Intentionality of effect

2. Kemampuan (Skills) Berdasarkan Literasi Media

Literasi media membutuhkan kemampuan yang spesifik yang kerap dinamakan dengan media literacy skills atau kemampuan literasi media. Center For Media Literacy (CML) mendefinisikan literasi media sebagai suatu kerangka kerja untuk mengakses, menganalisis, mengevaluasi, dan menciptakan media. Kemampuan literasi media mencakup: (1) Kemampuan mengkritik media. (2) Kemampuan memproduksi media. (3) Kemampuan mengajarkan tentang media. (4) Kemampuan mengeksplorasi sistem pembuatan pesan media. (5) Kemampuan mengeksplorasi berbagai posisi. (6) Kemampuan berfikir kritis (Tamburaka, 2013: 10). Menurut Potter (2001: 16), terdapat 7 keterampilan (skills) yang dibutuhkan untuk meraih kesadaran kritis bermedia melalui literasi media, yaitu: (1) Analisis (2) Evaluasi (3) Pengelompokan (4) Induksi (5) Deduksi (6) Sintesis (7) Abstracting.

\section{KELUARGA}

Fungsi Pokok Keluarga menurut Friedman (dalam Murwani, 2007): (1) Fungsi Afektif: berhubungan erat dengan fungsi internal keluarga yang merupakan basis kekuatan keluarga. (2) Fungsi Sosialisasi: proses perkembangan dan perubahan yang dilalui setiap anggota keluarga, yang menghasilkan interaksi sosial. Keluarga merupakan tempat setiap anggota keluarga untuk belajar bersosialisasi, keberhasilan perkembangan yang dicapai anggota keluarga melalui interaksi atau hubungan antara anggota keluarga diwujudkan dalam sosialisasi. (3) Fungsi Ekonomi: fungsi keluarga untuk memenuhi kebutuhan seluruh anggota keluarga (4) Fungsi Perawatan Kesehatan: Keluarga juga berfungsi untuk melaksanakan praktek asuhan kesehatan, Kemampuan keluarga dalam memberikan asuhan kesehatan mempengaruhi status kesehatan keluarga. Kesanggupan keluarga melaksanakan 
pemeliharaan kesehatan dapat dilihat dari tugas kesehatan keluarga yang dilaksanakan. Keluarga yang dapat melaksanakan tugas kesehatan berarti sanggup menyelesaikan masalah kesehatan (http://repository.usu.ac.id).

\section{PERKEMBANGAN ANAK}

Salah satu tugas perkembangan awal masa kanak-kanak yang penting adalah memperoleh latihan dan pengalaman pendahuluan yang diperlukan untuk menjadi anggota "kelompok" dalam akhir masa kanak-kanak. Keterampilan motorik yang berkembang baik mendorong anak untuk aktif dalam permainan dan konstruksi sedangkan keterampilan motorik yang buruk mendorong anak untuk menghabiskan waktu bermain dengan hiburan (Hurlock, 1999: 122).

Gencarnya iklan di televisi, semakin mempersulit upaya anak untuk menunda keinginannya. Untuk mencegah anak-anak menjadi korban iklan orangtua perlu memberikan pendidikan kepada anak agar mereka kritis terhadap iklan multimedia ini. Sambil menonton televisi bersama anak, jelaskan hasil rekayasa kecanggihan teknologi multimedia ini. Sambil menonton televisi bersama anak, jelaskan bahwa semua yang nampak indah dan lezat di televisi, adalah merupakan hasil rekayasa kecanggihan teknologi semata, sementara benda aslinya tidak persis seperti demikian (Istadi, 2006: 125).

\section{METODE PENELITIAN}

Penelitian ini menggunakan metode deskriptif kualitatif untuk mendapatkan data yang mendalam, suatu data yang mengandung makna. Metode penelitian deskriptif kualitatif sebagaimana menurut Bogdan dan Taylor (Moleong, 2011: 4) sebagai prosedur penelitian yang menghasilkan data deskriptif berupa kata-kata tertulis atau lisan dari orangorang dan perilaku yang dapat diamati. Metode kualitatif menyajikan secara langsung hakikat hubungan antara peneliti dan informan, objek dan subjek penelitian” (Sugiyono, 2008: 3). Kriteria dalam pemilihan informan dalam penelitian ini, yaitu: (1) Informan merupakan orangtua yang terdiri dari Ayah yang berkerja dan Ibu yang tidak berkerja. (2) Informan merupakan orangtua yang memiliki anak berusia 6-9 tahun. Kriteria tersebut peneliti pilih berdasarkan dari presentasi dari Budiningsih dari Fakultas Ilmu Pendidikan (FIP), Universitas Negeri Yogyakarta (UNY) yang menyatakan bahwa berdasarkan penelitian yang telah dilakukan Masyarakat Peduli Media (MPM, 2010) bahwa 50\% kemampuan belajar seseorang ditentukan ketika ia berusia 4-5 tahun, dan 30\% dibentuk sampai dengan usia sekitar 9 tahun, sedangkan pengetahuan yang diperoleh sesudah itu dibangun di atas dasar yang sudah ada. Subjek dalam penelitian ini adalah kelurga yang terdiri dari Ayah dan Ibu. Objek penelitian ini meliputi: struktur pengetahuan literasi media dan keterampilan (skills) literasi media. Teknik pengumpulan data dalam penelitian ini: wawancara mendalam (depth interview) dan dokumentasi. Verifikasi data dalam penelitian ini triangulasi, member checking dan Expert Opinion (EO). Penelitian ini dilakukan di SD Islam Al Ulum Terpadu Medan, SD Islam Al Ulum Terpadu dari bulan November 2015 Januari 2016. 


\section{PEMBAHASAN}

Penelitian mengenai literasi media televisi dalam keluarga dilakukan terhadap kedua orangtua, karena keluarga merupakan tempat dimana anak tumbuh kembang selain dari sekolah. Keluarga yang berhasil diwawancarai oleh peneliti: keluarga Desi Ariandi (DA) \& Murika (MR), Subhan Aulia (SA) \& Suryani (SY), Alamanda (AM) \& Herinaldi (HN), dan keluarga Darmawan (DW) \& Rafika Chinthia Dewi (RCD).

\section{Struktur Pengetahuan Literasi Media Yang Dipahami Oleh Orangtua Dalam Pendampingan Menonton Televisi Pada Anak Di Sd Al Ulum Medan}

Komponen yang perlu dipenuhi oleh keluarga dalam melaksanakan fungsi afektif adalah: 1. Saling mengasuh, cinta kasih, kehangatan, saling menerima, saling mendukung antar keluarga, sehingga tercipta hubungan yang hangat dan saling mendukung. 2. Saling menghargai, mengakui keberadaan dan hak anggota keluarga. 3. Ikatan kekeluargaan yang kuat dikembangkan melalui proses identifikasi dan penyesuaian pada berbagai aspek kehidupan anggota keluarga

a. Struktur pengetahuan isi media (Media Content)

Berdasarkan hasil penelitian bahwa pemahaman tentang literasi media dimulai dari struktur pengetahuan isi media. Isi media merupakan suatu program yang dirancang untuk menarik perhatian khalayak, sehingga khalayak pun merasa bahwa program tersebut dapat memenuhi kebutuhannya, baik memenuhi kebutuhan akan informasi sampai pada tingkat hiburan. Pada saat program acara ditayangkan oleh stasiun televisi, tidak semua program acara layak untuk ditonton terutama bagi anak-anak. Pemikiran terpenting dalam teori uses and effects adalah: penggunaan media massa dapat memiliki banyak arti dimana isi media tertentu dikonsumsi dalam kondisi tertentu, untuk memenuhi fungsi tertentu dan terkait harapan-harapan tertentu untuk dapat dipenuhi, dan kebutuhan hanya salah satu dari faktor yang menyebabkan terjadinya penggunaan media. Pada keluarga informan terdapat proses pendampingan pada saat anak menonton televisi. Proses pendampingan dilakukan oleh orangtua sebagai bentuk perhatian orangtua kepada anaknya, terkadang dilakukan oleh kedua orangtua apabila mereka secara bersama-sama memiliki waktu senggang, namun pendampingan sendiri bisa dilakukan oleh salah satu pihak orangtua saja. Hal ini wajar saja terjadi dikarenakan kedua orangtua masing-masing memiliki aktivitas terlebih lagi untuk seorang ayah yang berkerja.

Struktur pengetahuan isi media merupakan salah satu komponen penting dari literasi media karena pesan media yang diterima ataupun yang disampaikan oleh media televisi tidak seperti yang selalu terlihat, terkadang isi pesan tersebut ambigu atau memiliki makna ganda dan juga mencoba mempengaruhi khalayak yang menerimanya. Potter menyebutkan bahwa manusia berada pada dua dunia yakni dunia nyata dan dunia media. Pada hasil penelitian orangtua sudah menyetujui adanya dunia nyata dan dunia media tersebut, seluruh program yang diproduksi oleh media televisi tidak selalu sama dengan kondisi dunia yang sebenarnya. Efek media seperti inilah yang kemudian disebut sebagai fenomena konstruksi realitas oleh media dan hal ini sesuai dengan hasil penelitian.

Berdasarkan hasil penelitian, orangtua belum menyadari bahwa tidak semua jenis kartun baik untuk ditonton oleh anak-anak, terkadang ada juga kartun yang memberikan 
unsur sensual dan juga unsur kekerasan. Namun pada hasil penelitian ini orangtua baru menyadari hiburan yang tidak baik untuk anak-anak baru pada batas menonton sinetron saja. Expert Opinion (EO) pun menyatakan bahwa tidak semua kartun cocok ditonton oleh anak-anak seperti dicontohkan film kartun Tom and Jerry atau Spongebob, pada film ini pun mengandung unsur kekerasan di dalamnya. Berdasarkan hasil penelitian bahwa banyak tema yang disajikan oleh media televisi untuk khalayak atau penonton, sebagai orangtua sudah memiliki kesadaran bahwa ada beberapa tema yang tidak sesuai untuk ditayangkan baik itu untuk anak-anak maupun untuk diri orangtua itu sendiri walaupun tujuan dari program acara tersebut sebenarnya untuk menghibur. Walaupun ada beberapa tema yang tidak mereka setujui tetapi mereka belum pernah memberikan kritik atau saran yang membangun ke salah satu stasiun televisi.

b. Struktur Pengetahuan Industri Media

Tujuan pada media literacy strategy yakni untuk memahami dunia ekonomi dalam industri media. Hasil penelitian menunjukkan pemahaman orangtua bahwa iklan dalam suatu program acara televisi sangat penting, mereka juga mengetahui dengan pasti bahwa seberapa banyak iklan yang tayang dalam satu program acara akan dipengaruhi oleh ratting acara tersebut. Namun dari hasil penelitian para kedua orangtua tidak mengetahui bagaimana cara suatu program televisi diproduksi. Mereka hanya mengetahui produksi secara umum saja bahwa suatu produksi program acara hanya ada produser, sutradaranya saja. Berdasarkan hasil penelitian bahwa pengetahuan orangtua terhadap industri media berada pada tingkat pemahaman yang baik, mereka memahami bahwa media sebagai industri kini memiliki keberpihakan terutama dalam kancah politik, selain itu bahwa media bukan hanya sebagai pemberi informasi dan hiburan semata tetapi ada maksud mencari keuntungan materil dalam memperbesar industrinya.

c. Struktur Pengetahuan Efek Media

Menurut Potter terdapat empat pengetahuan efek, yaitu:

1. Timing of Effect

Timing of effect merupakan efek media bersifat jangka pendek maupun jangka panjang. Berdasarkan hasil penelitian bahwa anak-anak mengalami efek jangka pendek setelah menonton salah satu acara yang ditayangkan di televisi. Efek yang muncul antara lain ketidakstabilan emosi. Pada saat anak menonton televisi efek jangka pendek pasti terjadi karena anak belum mampu memisahkan mana yang boleh ditiru dan mana yang tidak boleh ditiru. Apabila efek negatif dalam jangka waktu pendek terus tertimbun tanpa ada netralisasi dari orangtuanya maka hal tersebut akan mempengaruhi anak dalam jangka waktu panjang dan untuk menetralisasikannya akan semakin sulit dan memerlukan waktu yang cukup lama pula. Hal ini sesuai dengan apa yang disampaikan oleh Expert Opinion.

2. Type of effect

Terdapat lima tipe efek yaitu:

Efek kognitif (cognitive type effect) merupakan efek yang berhubungan dengan kemampuan dalam berfikir dengan memanfaatkan pengetahuan yang didapatnya. Berdasarkan hasil penelitian banyak pengetahuan yang bisa didapat dari media televisi namun hal ini juga untuk program-program acara tertentu saja. Sesuai dengan hasil penelitian, program acara seperti laptop si unyil, kemudian acara live show tentang 
kesehatan, acara memasak, acara seperti Mario teguh dan Kick Andy banyak memberikan pengetahuan bagi khalayaknya. Melalui hal ini saja sebenarnya orangtua dapat mengambil hal yang positif dari banyaknya pesan yang diberikan televisi. hal itu pun dapat terjadi berdasarkan pemilihan program acara serta pesan yang hendak disampaikan oleh acara tersebut.

Efek sikap (attitudinal type effect) dapat berlangsung dalam jangka waktu pendek ataupun dalam jangka waktu panjang tergantung dari seberapa lama ia terpapar oleh media televisi. Media televisi merupakan media yang sangat menyenangkan bagi anak karena terdapat suara dan gerak yang dapat menghidupkan suasana. Terkadang hal yang menyenangkan ini dapat menghasilkan perubahan sikap anak. Nilai-nilai positif yang telah ditanam oleh orangtuanya dapat bergeser apabila terpaan media terlalu banyak tanpa adanya proses pendampingan dari pihak orangtuanya. Namun pada saat anak didampingi maka pada saat ia diterpa oleh media maka perubahan sikapnya akan mengarah pada hal yang positif.

Efek emosi (emosional type effect) bergerak pada tataran reaksi emosi, media dapat membuat kita merasakan sesuatu misalnya memicu emosi marah, sedih, bosan, dan lain-lain. Reaksi emosi ini berkaitan dengan perubahan psikologis. Perubahan emosi sering terjadi pada khalayak yang menonton, dikarenakan khalayak dapat terbawa suasana terhadap acara yang ditontonnya. Perubahan suasana sendiri dapat membuat penonton menjadi sedih apabila menonton acara orang menangis, dapat juga merasa gembira apabila menonton acara yang mengundang tawa, bisa merasa marah pada saat menonton acara sinetron yang memancing emosi, ataw malah bisa merasa bosan karena jalan cerita yang dimainkan terlalu monoton. Berdasarkan hal ini secara sadar orangtua sebagai salah satu khalayak dari media telivisi hendaknya mampu lebih dapat mengontrol efek emosi yang diakibatkan oleh televisi. Sehingga pada saat mendampingi anak menonton televisi orangtua mampu mengarahkan efek emosi anak, dan bukan malah ikut terbawa dalam suasana acara yang ditonton oleh anak.

Efek psikologis (psychological type effect) bisa mengarah pada efek yang positif ataupun negatif. Tanpa memiliki pengetahuan yang cukup terhadap media televisi hal ini bisa saja terjadi tanpa kita sadari sepenuhnya. Karena media dapat mempengaruhi sistem otomatis dalam tubuh (automatic bodily system) yang terjadi diluar kesadaran kita. Berdasarkan hasil penelitian, anak-anak lebih mudah terkena efek psikologis yang negatif dibandingkan orangtuanya. Namun efek psikologis yang negatif ini dapat berubah ke arah yang positif apabila orangtua mampu mendampingi dan memberikan informasi yang seimbang.

Efek perilaku (behavioral type effect) tersebut juga dapat bersifat jangka panjang. Hal ini sesuai dengan hasil penelitian bahwa anak-anak lebih cepat terpengaruh dengan adanya iklan yang ditayangkan oleh televisi dikarenakan iklan yang ada di televisi sangat menarik, baik itu dari bentuk makanan, ekspresi dari rasanya, warna dari produknya serta jingle musik sebagai pengiring iklannya. Tugas orangtua untuk mengarahkan keinginan anak agar anak tidak menjadi konsumerisme. Dalam mengarahkan keinginan anak menjadi konsumerisme dengan cara mendampingi mereka pada saat menonton televisi. Pada saat mendampingi anak menonton televisi, 
orangtua bisa menjelaskan dengan baik kepada anak-anak produk apa saja yang cocok digunakan atau makanan apa yang memang sesuai dengan kebutuhan mereka.

3. Valance of effect

Hal ini berkaitan dengan kecermatan kita dalam memanfaatkan media, apakah kita hanya akan dimanfaatkan oleh media mulai dari cara berfikir, opini, sikap, emosi, perilaku sampai pada psikologis yang kita miliki. Atau malah sebaliknya kita yang akan memanfaatkan media sebaik-baiknya untuk kepentingan diri kita baik itu dalam menambah wawasan, informasi maupun hiburan. Berdasarkan hasil penelitian bahwa orangtua menggunakan media ke arah yang positif, dimana efek yang dimanfaatkan untuk mencapai tujuan personal mereka.

4. Intentionality of effect

Berdasarkan dari hasil penelitian menunjukkan bahwa program yang ditayangkan oleh televisi hendaknya melakukan penyensoran atau setidaknya memberikan contoh adegan yang baik sehingga dapat membawa efek positif terutama apabila program tersebut dihadirkan untuk ditonton oleh anak-anak.

\section{Keterampilan (Skills) Literasi Media Yang Dibutuhkan Orangtua Pada Saat Mendampingi Menonton Televisi Pada Anak Di SD Al Ullum Medan}

Menurut Potter, terdapat tujuh keterampilan (skills) yang dibutuhkan untuk meraih kesadaran kritis bermedia melalui literasi media. Pada hasil penelitian bahwa orangtua sudah menjelaskan esensi dari isi pesan yang diterima oleh anak dengan cara menjelaskan sebab dan akibat dari satu pesan yang diterima oleh anak. Penjelasan orangtua terhadap isi pesan yang yang diterima oleh anak sangat diperlukan, karena hal ini akan mempengaruhi pembentukan pada pola pikir anak. Berdasarkan dari analisis ketujuh keterampilan yang dibutuhkan oleh orangtua hal ini masih ada yang belum sesuai dengan Silverblatt yang telah mengidentifikasikan lima elemen literasi media. Kesesuaian dan ketidaksesuaian tersebut, yaitu:

1. Orangtua sudah mulai menyadari dan memahami bahwa adanya dampak media terhadap diri individu anak maupun pada dirinya sendiri.

2. Orangtua baru hanya memahami tentang komunikasi massa tetapi belum sampai pada prosesnya.

3. Pengembangan strategi untuk menganalisis belum dilakukan karena orangtua baru menganalisis jenis pesan dan program acaranya saja. Mendiskusikan pesan media baru dilakukan apabila anak bertanya kepada orangtua.

4. Orangtua sudah menyadari bahwa konten media merupakan sebuah teks yang memberikan pemahaman kebudayaan kita dan diri kita sendiri

5. Pemahaman kesenangan, pemahaman, dan apresiasi yang dimiliki oleh orangtua belum ditingkatkan terhadap konten media. 


\section{E. SIMPULAN}

\section{Simpulan}

1. Tiga struktur pengetahuan literasi media yang perlu dipahami oleh orangtua pada saat pendampingan menonton televisi pada anak yakni:

a. Pengetahuan terhadap isi media

Pengetahuan orangtua terhadap isi (content) media, baru pada tingkat memahami program mana yang baik atau tidak dan orangtua belum memahami secara detail tentang pengetahuan isi (content) media secara keseluruhan.

b. Pengetahuan terhadap industri media

Pengetahuan orangtua terhadap industri media berada pada tingkat pemahaman yang baik, mereka memahami bahwa media sebagai industri kini memiliki keberpihakan terutama dalam kancah politik, selain itu bahwa media bukan hanya sebagai pemberi informasi dan hiburan semata, tetapi ada maksud mencari keuntungan materil untuk memperbesar industrinya.

c. Pengetahuan terhadap efek media

Orangtua sudah memahami dan menyadari efek yang terjadi baik pada diri si anak ataupun pada dirinya sendiri.

2. Tujuh keterampilan (skills) yang dibutuhkan orangtua pada saat pendampingan menonton televisi pada anak yaitu: (a) Analisis: Orangtua mengetahui dengan baik informasi apa saja yang dibutuhkan oleh anak-anak. Namun orangtua masih menganggap bahwa film kartun merupakan film yang baik untuk ditonton oleh anak. (b) Evaluasi: Orangtua memahami dengan baik bagaimana caranya mengevaluasi baik dari segi pesannya, media televisinya (stasiun televisi), sampai pada program acaranya. (c) Pengelompokan: Pemberian informasi yang seimbang dilakukan dengan cara spontan pada saat proses pendampingan berlangsung, kemudian pengelompokkan informasi juga dilakukan dengan cara menukarkan program acara apabila acaranya tidak sesuai dengan usia anak kemudian orangtua mengetahui program acara apa saja yang sesuai untuk anak-anak. (d) Induksi: Orangtua sudah mampu mengambil kesimpulan atas pengelompokan informasi dalam sebuah program acara yang kemudian melakukan generalisasi atas pola-pola elemen atau pada jenis pesan-pesannya tersebut ke dalam pesan yang lebih besar. (e) Deduksi: Orangtua sudah mampu menjawab pertanyaan dari anak-anak mengenai informasi apa yang tidak dipahami oleh anak sampai pada pertanyaan yang membutuhkan jawaban yang lebih spesifik lagi untuk menghilangkan rasa penasaran anak. (f) Sintesis: Dari hasil penelitian dapat disimpulkan bahwa orangtua memiliki peranan aktif dalam memilihkan program acara yang akan ditonton oleh anak, kemudian anak juga masih dalam proses pengawasan orangtua pada saat mereka menonton televisi. (g) Abstraksi: Orangtua sudah menjelaskan esensi dari isi pesan yang diterima oleh anak dengan cara menjelaskan sebab dan akibat dari satu pesan yang telah diterima oleh anak. 


\section{Saran}

1. Orangtua membatasi jam menonton anak.

2. Apabila terdapat program acara yang tidak sesuai maka orangtua mengganti channel stasiun televisi, namun alangkah lebih baiknya jika orangtua terlebih dahulu menjelaskan informasi dari program acara yang tidak sesuai tersebut agar anak tidak menjadi penasaran. Orangtua menjawab semua pertanyaan anak tentang informasi dari acara yang ditontonnya. Orangtua memilihkan acara yang tepat untuk dapat ditonton anak.

3. Manfaat praktis: Penelitian ini diharapkan dapat lebih memberikan masukan bagi pihak keluarga agar dapat memahami tentang bagaimana memilih dan memahami isi konten media yang diberikan kepada anak, sehingga manfaat yang terkandung dalam media dapat memberikan perilaku positif dan baik untuk perkembangan anak.

\section{DAFTAR PUSTAKA}

Arikunto, Suharsimi. 1998. Prosedur Penelitian Suatu Pendekatan Praktek. Jakarta: Rineka Cipta,

Baran, Stanley J. 2011. Pengantar Komunikasi Massa Literasi Media dan Budaya. Jakarta: Salemba Humanika

Bryant, Jennings and Susan Thompson. 2002. Fundamentals of Media Effects. McGrawHill.

Bungin, Burhan. 2006. Sosiologi Komunikasi: Teori, Paradigma dan Diskursus Teknologi Komunikasi di Masyarakat. Jakarta: Kencana Prenada Media.

Creswell, John W. 2010. Research Design Pendekatan Kualitatif, Kuantitatif, dan Mixed. Yogyakarta: Pustaka Pelajar.

Ginting, Rahmanita. (2015). Peran Literasi Media Dalam Era Komunitas Asean. Dalam Ambang Priyonggo, FX Lilik Dwi M., Adi Wibowo. Dinamika Media Pada Masyarakat Kontemporer Indonesia. UMN Press: Tangerang-Banten.

Hurlock, E.B. 1999. Psikologi Perkembangan. Jakarta: Erlangga.

Istadi, Irawati. 2006. Melipat Gandakan Kecerdasan Emosi Anak. Bekasi: Pustaka Inti. KPI. 2012. Meretas Jalan Sosialisai Literasi Media di Indonesia. Jakarta: KPI

Masyarakat Peduli Media (MPM). 2010. Ketika Ibu Rumah Tangga Membaca Televisi. Yogyakarta: Tifa Foundation.

Masyarakat Peduli media. 2012. Pengaruh televisi terhadap perkembangan karakter anak. http://pedulimedia.or.id/2012/11/10/pengaruh-televisi-terhadapperkembangankarakter-anak/2/.

Moleong, L. J. 2011. Metodologi Penelitian Kualitatif. Bandung: Remaja Rosdakarya.

Murwani, Arita. 2007. Asuhan Keperawatan Keluarga Konsep dan Aplikasi Kasus. Jogjakarta: Mitra Cendikia Press.

Potter, W. James. 2001. Media Literacy, Second Edition. Sage Publications, Oak-London. Rifiani, Nisya. 2014. Studi Literasi media. https://id.scribd.com/doc/229115779/StudiLiterasi-Media 
Risantino, Welga Febdi. Memulai Literasi Media Televisi pada Keluarga di Masyarakat Pandalungan Kabupaten Jember: Sebuah Pendekatan Etnografi Kritis. Malang: Universitas Brawijaya.

Ruben, Brent D. \& Stewart, Lea P. 2013. Komunikasi dan Perilaku Manusia. Jakarta: Raja Grafindo Persada.

Sendjaja, Sasa Djuarsa. 2004. Pengantar Komunikasi. Jakarta: Universitas Terbuka.

2005. Teori Komunikasi Massa: Media, Effect, dan Audience. Jakarta: Universitas Terbuka.

Sugiyono. 2008. Memahami Penelitian Kualitatif. Bandung: Alfabeta.

Tamburaka, Apriadi. 2013. Literasi Media: Cerdas Bermedia Khalayak Media Massa. Jakarta: Rajawali Pers.

Wahyudi, J. B. 1986. Media Komunikasi Massa Televisi. Bandung: Alumni.

West, R., \& Turner, L. H. 2010. Introducing Communication Theory; Analysis and Application (Pengantar Teori Komunikasi: Analisis dan Aplikasi) (Ed. 3). Jakarta: Salemba Humanika.

http://alulumterpadu.blogspot.com/ 